\title{
Termal Ön İşlemin Güneş Enerjili Raflı Bir Kurutucuda Muz Cipsi Üretimine Etkisi
}

\author{
Zehra YILDIZ ${ }^{* 1}$ \\ ${ }^{1}$ Tarsus Üniversitesi, Mühendislik Fakültesi, Makine Mühendisliği Bölümü, Mersin
}

Öz: Gıda ürünlerinin uzun süre muhafaza edilmesi için doğrudan güneşışınımı altında kurutulması durumunda özellikle ürünün renginde bozulma ve besin değerlerinde azalma meydana gelmektedir. Bu sebeple, güneşin etkisinden dolaylı faydalanılabilen güneş enerjili kurutucular kullanılmaktadır. Bu çalışmada, termal ön işlem uygulanmış ve uygulanmamış muz halkaları güneş enerjili raflı kurutucuda kurutulmuştur. Halka halinde kesilmiş muz önce belirli sıcaklıkta bulunan su, şeker ve sitrik asit çözeltilerinden birine daldırımış daha sonra güneş enerjili kurutucuda kurutulmuştur. Kurutma koşulları, ön işlem, çözelti türü ve güneş enerjili kurutucuda kalma süresi olarak belirlenmiştir. Kurutma koşullarının nem kaybı, çapsal büzülme oranı ve renk parametrelerine etkisi belirlenmiştir. Muz halkalarının kurutulmasında en uygun daldırma çözeltisi sitrik asit çözeltisi olarak belirlenmiştir. Sitrik asit çözeltisine daldırılan muz halkaları güneş enerjili raflı kurutucunun yanı sıra güneş altında ve gölgede kurutulmuştur. Muz halkalarının kurutulması üzerine raflı güneş enerjili kurutucuda kurutulmadan önce termal ön işlem uygulanmasının olumlu etkisi olduğu belirlenmiştir. Muz halkalarının batırıldığı çözelti türü ve kurutucuda kalma süresinin artmasıyla ile hem çapsal büzülme oranı hem de nem kaybı artmıştır.

Anahtar kelimeler: Kurutma, Güneş enerjili kurutucu, Kurutma ön işlemi

The Effects of Thermal Pre-treatment on the Production of Banana Chips using Solar Tray Dryer

\begin{abstract}
If food products are dried under direct sunlight to preserve them for a long time, deterioration in the color of the product and decrease in nutritional values occur. For this reason, solar-powered dryers are used that can benefit indirectly from the effect of the sun. In this study, the banana rings with and without thermal pre-treatment were dried in a solar rack dryer. The banana rings was first dipped in one of the water, sugar and citric acid solutions at a certain temperature and then dried in a solar tray dryer. Drying conditions were determined as pretreatment, solution type and residence time in solar dryer. The effect of these drying conditions on banana drying was determined as moisture loss, diameter shrinkage ratio and b color parameters. The most suitable dipping solution for drying banana rings was determined as citric acid solution. Banana rings soaked in citric acid solution were dried in the sun and in the shade as well as in a solar rack dryer. It was determined that applying thermal pre-treatment on the drying of banana rings before drying in a rack solar dryer has a positive effect. With the increase in the concentration of the solution in which the banana rings were kinds of solution and the solar dryer time increased, both diameter shrinkage ratio and moisture loss increased.
\end{abstract}

Keywords: Drying, Solar dryer, Pre-drying treatment

\section{GiRiş}

Muz, yaz ve kış tüketicinin severek tükettiği ancak diğer meyvelere göre çok çabuk bozulabilen tropikal bir meyvedir. Ülkemiz, muz tüketiminin yarısını karşılamaktadır. Yerli muz üretimi, Antalya ve Mersin illerinde yapılmaktadır. Mersin, muz üretiminin \%73 lük kısmını karşılamaktadır. Mersin ilinde Anamur, Bozyazı ve Erdemli ilçeleri başta olmakla beraber Aydıncık, Yenişehir, Toroslar, Tarsus, Akdeniz, Silifke ilçelerinde muz üretimi yapılmaktadır. Mersin'de en fazla üretilen 4. meyve muzdur ve bölgedeki tarımın kalkınmasında çok önemli bir gıda ürünüdür (Subaşı ve ark., 2016; Akova ve Güven, 2018).

Muz, çok çabuk bozulan bir meyve olduğundan uzun süre muhafaza edilmesi depolamada önemli bir sorundur. Muzun ilk nem içeriği \%80 olup, nem içeriği \%15 olana kadar kurutulduğunda raf ömrü uzatılabilir. Muzun kurutulması için gereken hava sıcaklığı yüksek olup, $70^{\circ} \mathrm{C} \mathrm{dir}$ (Ertekin ve Yaldız, 1998). Türkiye de en fazla güneşlenme süresinin olduğu temmuz ayında Türkiye güneşlenme süresi 11.31 saat olup, Mersin için güneşlenme süresi 11.45 saat ve Tarsus ilçesinin güneşlenme süresi 11.63 saattir (Enerji İşleri Genel Müdürlüğü, 2021). Mersin ilinin güneşlenme süresi, Türkiye güneşlenme süresinin üzerinde olup, güneşlenme potansiyeli oldukça yüksek olan ve birinci kuşakta yer alan bir ildir (Buldum, 2008). Güneş ışınımının yüksek olduğu ülkelerde, ürünlerin güneşte kurutulması oldukça yaygın kullanılan bir gıda koruma yöntemidir. Besin değerleri ve duyusal özellikleri yüksek kuru ürünlerin ekonomik üretimi için en uygun kurutma yöntemi seçilmelidir. Bugün dünya üzerinde pek çok ülkede ürünler doğrudan güneş altında kurutulmaktadır. Doğrudan güneş altında kurutma yöntemi, ekonomik bir kurutma yöntemi olmasına karşın açık alanda kurutma yapıldığından kurutulacak ürünün toza, kire ve çeşitli haşeratlara maruz kalması gibi durumlardan dolayı hijyenik bir kurutma sağlamaz. Ürün, güneş altında doğrudan güneş ışınına maruz kaldığından ürünün rengi, tat, aroma, gevreklik gibi duyusal özellikleri ve besin değerleri olumsuz etkilenmektedir (Eren, 2004; Erünal, 2010; Yıldız ve Gökayaz 2018). Kurutma işlemini etkileyen en önemli faktörlerden

*Sorumlu Yazar: zyildiz@tarsus.edu.tr

Geliş Tarihi: 30 Nisan 2020

Kabul Tarihi: 12 Mart 2021 
biri kurutma havasının özellikleridir. Kurutma havasının neminin yüksek olması kurutma işlemini olumsuz etkiler. Mersin, yaz mevsiminde hava sıcaklığı ve hava nemi Türkiye ortalamasının üzerinde olan bir ildir. Güneş enerjisinden dolaylı olarak yararlanıldığı güneş kolektörlerine sahip kurutucularda hava sıcaklığı dış ortamdan daha yüksek olup, hava nemi daha azdır (Lingayat ve ark., 2017). Ayrıca güneş altında kurutmada çok geniş arazilere ihtiyaç olup, çok raflı güneş enerjili kurutucular daha az yer kaplar, güneşin doğrudan teması ile kurutulacak üründe renk, duyusal ve besin değerlerindeki kayıplar önlenebilir, daha kısa sürede kurutma sağlanabilir.

Kurutulacak ürünün kalitesi ve işletme maliyeti üzerine kurutma öncesi uygulanacak sıcak daldırma, soğuk daldırma, haşlama, kükürtleme, tuzlama ve ozmotik dehidrasyon gibi ön işlemlerin önemli etkileri bulunmaktadır (Yokuş, 2014). Kurutma ön işlem uygulanması ile ilgili araştırmalar son yıllarda ilgi çekmektedir. Daldırma ve haşlama işlemi, enzim aktivitesini durdurmayı veya yavaşlatmayı sağlayarak besin kalitesinin, duyusal özellikler ve rengin korunmasına yardımcı olarak daha kısa sürede kurutmayı sağlar (Gürel ve ark., 2016). Daldırma ve haşlama işlemi ürünün yapısı, şekli, boyutu, çözelti sıcaklığı ve derişimi, çözelti ürün oranı gibi faktörlere bağlıdır (Fernandes ve ark., 2006).

Güneş enerjili kurutucuda kurutma ile sıcak daldırma birlikte kullanılması ile kurutma işleminin verimi artırılabilir. Kurutmadan önce uygulanan ön işlem sırasındaki su kaybına bağ।ı olarak kurutucunun su uzaklaştırma yükü azalmakta, örnekler kurutucuya daha yüksek kuru madde içeriğinde girmektedir. Böylece ön işlem, kurutma süresini kısaltmayı ve kurutucu potansiyelini arttırmayı sağlar. Bununla birlikte, ön kurutma işlemiyle kurutulmuş örneklerin su alma özelliği gelişmiş, renk, doku, görünüş bakımından oldukça kaliteli ürünler oldukları, aroma ve tat açısından da kabul edilebilir düzeyde oldukları belirtilmektedir. Ayrıca bu yöntem kurutma için enerji gerektirmediğinden ekonomik bir kurutma yöntemidir (Nowakunda ve ark., 2004; Aktaş ve ark., 2006; Silva Júnior ve ark., 2017).

Muz cipsi, tatlı karışımlarında, çikolata, biskivü, kek ve kahvaltılık gevreklerde kullanılan ayrıca sağlıklı atıştırmalık olarak tüketilen besleyici özelliği yüksek olan kuru muz halkalarıdır. Bu çalışmada, kurutma termal ön işlemin (haşlama) uygulandığı ve uygulanmadığı ince dilimlenmiş muz halkaları güneş enerjili raflı kurutucuda kurutularak muz cipsleri elde edilmiştir. Muz halklarının güneş enerjili kurutucuda kurutulması üzerine termal ön işlemin etkisi belirlenmiştir. Belirli dilim kalınlığındaki muz halkaları çeşitli çözeltilere daldırılmış daha sonra güneş enerjili raflı kurutucuda kurutulmuştur. Muz halkalarının daldırıldığı çözelti türü, daldırma süresi ve güneş enerjili kurutucuda bekleme süresinin nem kaybı, büzülme oranı ve b sarılık renk değişimi üzerine etkileri belirlenmiştir. Ön işlem uygulanmış muz halkaların nem kaybı ile beraber büzülme oranı artarken renk değişimi gözlenmiştir.

\section{MATERYAL VE YÖNTEM}

Bu çalışma kapsamında muz kurutmada kullanılacak olan çok raflı doğal konvektif güneş enerjili kurutucu özel olarak tasarlanmıştır. Şekil 1'de gösterilen kurutucu; güneş kolektörü, kurutma odası ve bacadan oluşmaktadır. Kurutma odası içerisinde çıkarılıp takılabilir delikli raflar yerleştirilmiştir. Kolektörde yer alan yutucu plaka ile güneş ışınımları tutularak güneşten elde edilen ISı kurutma havasına aktarılır. Güneş kolektörü ile ısınan hava kurutma odasında yer alan delikli raflar üzerine yerleştirilmiş muz halkalarındaki nemi uzaklaştırır ve kurutucu bacasından nemli hava atılarak kurutma işlemi tamamlanır.

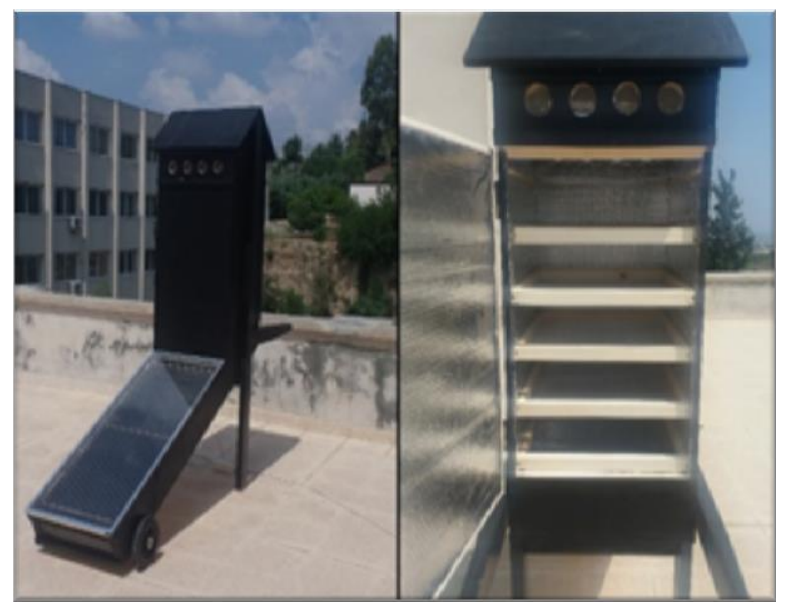

Şekil 1. Çok rafı ı doğal konvektif güneş enerjili kurutucu

Deneyler, global ışınım değerlerinin ve güneşlenme süresinin en yüksek olduğu Temmuz ve Ağustos aylarında yapılmıştır. Deneyler sıcaklık ve güneş ışınım şiddetinin en yüksek olduğu saatlerde 09:30 ile 17:30 da yapılmıştır (Apaydın, 2007). Güneş enerjili raflı kurutucu, deneylere başlanmadan önce termal dengeye gelmesi için güneş altında bir saat bekletilmiştir. Deneylerde Anamur muzu kullanılmıştır. Kabukları soyulan muzlar, $3 \mathrm{~mm}$ dilim kalınlığında halka şeklinde dilimlenmiştir.

Meyveler genellikle asidik çözeltilere daldırılmakta ve böylece ürün kalitesini etkileyen enzimler inaktive olmaktadır. Muz halkalarının ön işleminde şeker, bal, meyve suyu, limon suyu, askorbik asit çözeltisi ve sitrik asit çözeltisi kullanılmıştır (Abano ve Sam-Amoah, 2011; Pandya ve Yadav, 2014; Gürel ve ark., 2016). Bu çalışmada muz halkalarının ön işlemi için \%5 sitrik asit, \%5 şeker çözeltisi ve su (kontrol çözeltisi) kullanılmıştır. Muz halkalarının kurutulmasında termal ön işlemlerde çözelti sıcaklığı olarak genellikle $50{ }^{\circ} \mathrm{C}-70{ }^{\circ} \mathrm{C}$ aralığında alınmıştır (Fernandes ve ark., 2006; Taiwo ve Adeyemi, 2009; Sunitha ve ark., 2017). Muz halkalarına uygulanan kurutma öncesi daldırma ön 
işlemi için sitrik asit çözeltisine 10 dakika daldırılması çeşitli çalışmalarda önerilmiştir (Taiwo ve Adeyemi, 2009; Gürel ve ark., 2016). Sıcak su daldırma meyvede su geçişi ve çözünenlerin liçingini sağlar. Çözünen maddelerin geçişi daldırma zamanı ve sıcaklığına bağlıdır. $85{ }^{\circ} \mathrm{C}$ gibi yüksek daldırma sıcaklıklarında çözünen geçişi artarken meyvenin doku yapısı zarar görür (Jagannath ve Kumar, 2016). Sunithave arkadaşlarının yaptığı bir çalışmada $82{ }^{\circ} \mathrm{C}$ de 15 dk su da $3 \mathrm{~mm}$ dilim kalınlığında muz halkaları bekletilmiştir (Sunitha ve ark., 2017). Bu çalışmada, muz halkalarının termal ön işleminde çözelti sıcaklıkları doku kaybına yol açmayacak kadar yüksek bir sıcaklık olan $80^{\circ} \mathrm{C}$ seçilmiştir. \%5 sitrik asit çözeltisi, \%5 şeker çözeltisi ve kontrol çözeltisine ağırıkları, çapları ve renk parametreleri belirlenen muz halkaları $10 \mathrm{dk}$ boyunca batırılmıştır. Çözeltiden çıkarılan muz halkaları süzülerek daha sonra güneş enerjili kurutucunun rafına dizilerek kurutulmuştur. Ayrıca kurutma ön işleminin etkili olup olmadığını belirlemek için ön işleme tabii tutulmamış muz halkaları da güneş enerjili kurutucu da kurutulmuştur. Kurutma öncesi ve sonrası nem kaybı, büzülme oranı ve b renk parametre değişimi gibi kurutma performans değerleri belirlenmiştir.

$80{ }^{\circ} \mathrm{C}$ de 10 dakika, sitrik asit çözeltisi içerisinden alınan dilimlenmiş muzun fazla suyu süzdürüldükten sonra kurutma işlemleri için tepsilere yerleştirilmiştir. Toplam beş saat boyunca güneş enerjili kurutucuda muz halkaları kurutulmuştur. Bir saat aralıklarla muz halkalarının ağırlıkları, çapları ve renk parametreleri ölçülerek nem kaybı, çapsal büzülme oranı ve renk parametrelerindeki değişimi belirlenmiştir.

Kurutmaya etki eden faktörler olarak güneş enerjili kurutucuda kalma süresi, ön işlem ve çözelti türü seçilmiştir. Deneylerde belirlenen kuruma süreleri boyunca ağırlık ve çap ölçümleri ile beraber renk analizi yapılmıştır. Deneylerde kurutma işlemi öncesi ve sonrası ölçümler, üç örnek için yapılmış ve ortalaması alınmıştır. Deney sonucunda \%nem kaybı, çapsal büzülme oranı ve renk değişimi gibi kurutma verileri elde edilmiştir. Bu veriler aşağıdaki eşitlikler yardımıyla belirlenmiştir (Darıcı, 2012; Aboud, 2013; Pandya ve Yadav, 2014).

Nem Kaybı $=\frac{\mathrm{M}_{0}-\mathrm{M}_{\mathrm{S}}}{\mathrm{M}_{0}}$

Büzülme Oranı $=\frac{D_{0}-D_{S}}{D_{0}}$

Eşitlik 1'de yer alan $M_{0}$ ve $M_{S}$ sırasıyla muz halkalarının kurutma öncesi ve kurutma sonrası ağırlıklarını (g), eşitlik 2'de yer alan $D_{0}$ ve $D_{s}$ ise kurutma öncesi ve kurutma sonrası örnek çapını ( $\mathrm{mm}$ ) ifade etmektedir.

Muz halkalarının renk değişimi kaliteyi olumsuz etkileyen bir parametredir. Muz halkalarının oksidasyon sonucunda kararmasını engellemek ve kurutma süresini azaltmak için muz halkaları önce belirli derişimdeki farklı çözeltilere daldırılmıştır. b renk değeri, mavi-sarı renkleri hakkında bilgi verir. b pozitif değeri, sarı ve negatif değeri mavi rengi ifade eder. Muz halkaları beyaz-sarı renklerinde olup, zamanla sarı-kahverengi renk alır. Bu yüzden muz için b değerleri renk analizinde önemlidir (Yıldız ve ark., 2015). Renk ölçümü üç defa yapılmış ve ortalama değer alınmıştır. b renk değişimi aşağıdaki eşitlik yardımıyla hesaplanmıştır. Kurutma öncesi ve sonrası muz halkalarının renk parametresi b, Lab Tools un colorimeter yazılımı ile belirlenmiştir. $b_{0}$ taze muz halkalarına ait ve $b$ kurutma periyodu sonrası b renk parametresini göstermektedir (Askari ve ark., 2008).

$\frac{\Delta \mathrm{b}}{\mathrm{b}_{0}}=\frac{\mathrm{b}_{0}-\mathrm{b}}{\mathrm{b}_{0}}$

\section{BULGULAR VE TARTIŞMA}

Muz halkalarının kurutulması için ön işlem uygulanmış daha sonra çok raflı doğal konvektif güneş enerjili kurutucuda kurutma işlemi gerçekleştirilmiştir. Ön işlemin güneş kurutma üzerine etkileri Şekil 2, Şekil 3, Şekil 4, Şekil 5, Şekil 6 ve Şekil 7 de verilmiştir. Ön işlem uygulanmamış (ön işlemsiz) ve ön işlem uygulanmış muz halkaları, güneş enerjili kurutucu da kurutulmuş ve zamanla nem kaybındaki değişim Şekil 2 de verilmiştir. Kurutma süresi boyunca muz halkalarının nem kaybı şekilden görüldüğü üzere kurutma süresi boyunca artmıştır. Nemin difüzyonu, gıda ve kurutma havası arasındaki konveksiyonla ısı transferi ile gıdanın yüzeyinden su buharlaşma hızı, kurutma havasının sıcaklığının ve kurutma süresinin artması ile artar. Böylece, nem kaybı artar (Nwakuba ve ark., 2018; Abano ve ark., 2014; Cakir, 2015).

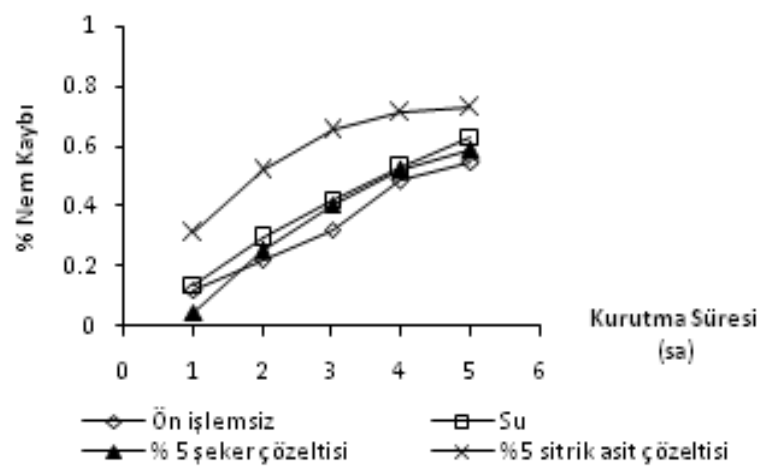

Şekil 2. Kurutma süresi boyunca nem kaybı değişimi

Şekilden görüldüğü üzere güneş enerjili kurutucuda ön işlem uygulanması nem kaybı değerini arttırmıştır. En fazla nem kaybı, \%5 sitrik asit çözeltisine daldırılan muz halkalarında görülmüştür. Yalnız güneş enerjili kurutucu ile kurutulan muz halkalarındaki nem kaybı en azdır. Kurutmanın ilk saatinde nem kaybı \%12 iken beş saatlik kurutma periyodunun sonunda nem kaybı \%55'e 
yükselmiştir. $80^{\circ} \mathrm{C}$ sıcaklıkta $10 \mathrm{dk}$ suya daldırılmış (kontrol çözeltisi) muz halkalarının kurutulmasında nem kaybı kurutmanın ilk saatinde $\% 14$ iken beş saatlik kurutma periyodunun sonunda nem kaybı $\% 63$ 'e yükselmiştir. $80{ }^{\circ} \mathrm{C}$ sıcaklıkta $10 \mathrm{dk} \% 5$ sitrik asit çözeltisine daldırılmış muz halkalarının kurutulmasında nem kaybı kurutmanın ilk saatinde \%31 iken beş saatlik kurutma periyodunun sonunda nem kaybı \%73'e yükselmiştir. $80{ }^{\circ} \mathrm{C}$ sıcaklıkta 10 dk \%5 şeker çözeltisine daldırılmış muz halkalarının kurutulmasında nem kaybı, kurutmanın ilk saatinde \%4.6 iken beş saatlik kurutma periyodunun sonunda nem kaybı \%58'e yükselmiştir.

Şekil 3 de ön işlemi uygulanmamış ve uygulanmış muz halkalarının güneş enerjili kurutucu da zamanla büzülme oranlarındaki değişime ait sonuçlar verilmiştir. Nem kaybı kurutma süresi boyunca azaldığı için büzülme oranı da artmıştır. Daldırma çözeltisi, muz dilimlerindeki gözenekleri güneşte kurutma süresince doldurarak genişletir ve ön işlem örneklerden nem giderme oranını arttırır (Abano and Sam-Amoah, 2011). Üründe nem içeriği azalırken katı matrisinin yoğunluğu çözücü geçişiyle artar (Talla ve ark., 2004).

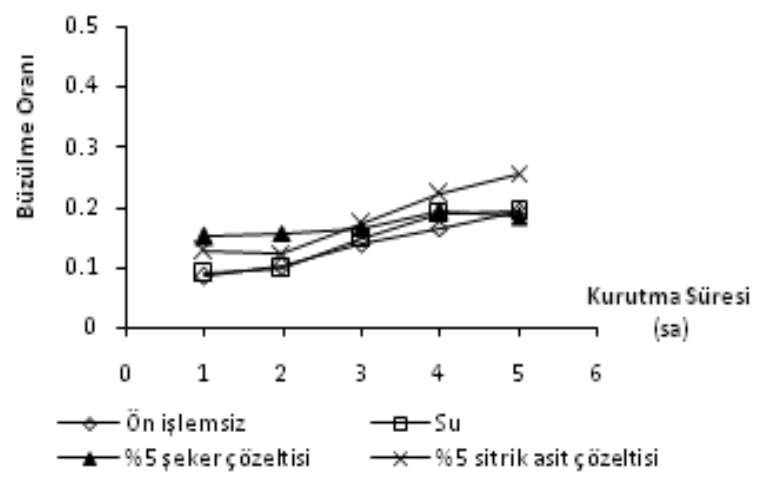

Şekil 3. Kurutma süresi boyunca büzülme oranı değişimi

$80{ }^{\circ} \mathrm{C}$ sıcaklıkta suya $10 \mathrm{dk}$ çeşitli çözeltilere daldırılan muz halklarında ön işlem uygulanmamış muz halkalarına göre daha fazla büzülme görülmüştür. Nem kaybında olduğu gibi en fazla büzülme oranı $\% 5$ sitrik asit çözeltisine daldırılan muz halkalarında görülmüştür. Ön işlemsiz muz halkalarının güneş enerjili kurutucu da kurutulmasında elde edilen büzülme oranı başlangıçta \%8.6 dan kurutma süresinin sonunda \%19'a artmıştır. Suya daldırılmış muz halkalarında büzülme oranında kurutma süresinin ikinci saatinden sonra artış olmuştur. Büzülme oranı $\% 9$ dan beş saatlik kurutma periyodunun sonunda \%28'e ulaşmıştır. \%5 şeker çözeltisine daldırılmış muz halkalarında kurutma süresince büzülme oranında önemli bir değişim görülmemiştir. \%5 sitrik çözeltisine daldırılmış muz halkalarında büzülme oranı, kurutma süresinin ikinci saatinden sonra artmıştır. Büzülme oranı $\% 14$ den kurutma süresinin son saatinde $\% 26$ olmuştur. Muz halkalarına uygulanan daldırılma işlemi büzülme oranını arttırmıştır.

Şekil 4 de, ön işlem uygulanmış ve uygulanmamış muz halkalarının güneş enerjili kurutucuda kurutma işlemi sonundaki renk değişimleri görülmektedir. Su ve şeker çözeltisine daldırılmış muz halkalarında kararma gözlenirken ön işlemsiz ve sitrik asit çözeltisine daldırılan muz halkalarında önemli bir kararma olmamıştır. Herhangi bir kurutma yöntemi ile kurutulan örnekteki koyulaşma gibi renk değişimi, luminosity gibi ısıya duyarlı pigmentlerin zarar görmesi ile ilgilidir. Sitrik asit, askorbik asit gibi asidik çözeltilere meyvenin daldırılması kahverengileşme ve enzimatik olmayan Milard reaksiyonunu engellediği bilinmektedir (Maskan, 2001).

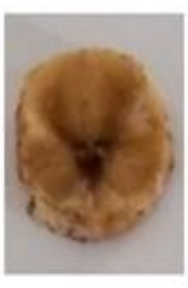

a

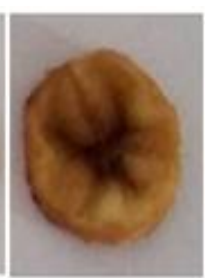

b

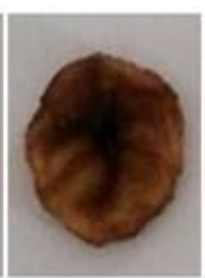

c

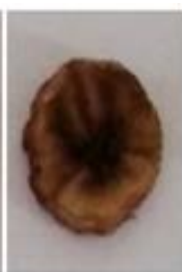

d
Şekil 4. Kurutma işlemi ile muz halkalarındaki renk değişimi a) Ön işlemsiz b) Sitrik aside daldırılmış c) Suya daldırımış d) Şeker çözeltisine daldırılmış

Şekil 5 de, ön işlem uygulanmış ve uygulanmamış muz halkalarının güneş enerjili kurutucuda kurutulmasında b renk parametresindeki değişim verilmiştir. Kurutma süresi boyunca muz halkalarının $\Delta b / b$ o oranı değişmiştir. Muz halkalarının sitrik asit çözeltisine daldırılması oksidasyonu yavaşlatarak muzun kararmasını önlemiş, gözle görülür bir kararma görülmemiştir. Kurutma süresinin üçüncü saatinden sonra b parametresinde düşüş görülmüştür. Muz halkalarının taze halindekine göre $b$ değeri daha yüksektir. Muz halkalarının şeker çözeltisine batırılması muzu karartmış ve muz halkalarının taze halindekine göre $b$ değeri daha düşük bulunmuştur. b sarılık renk parametresi ikinci saatten sonra azalmıştır.

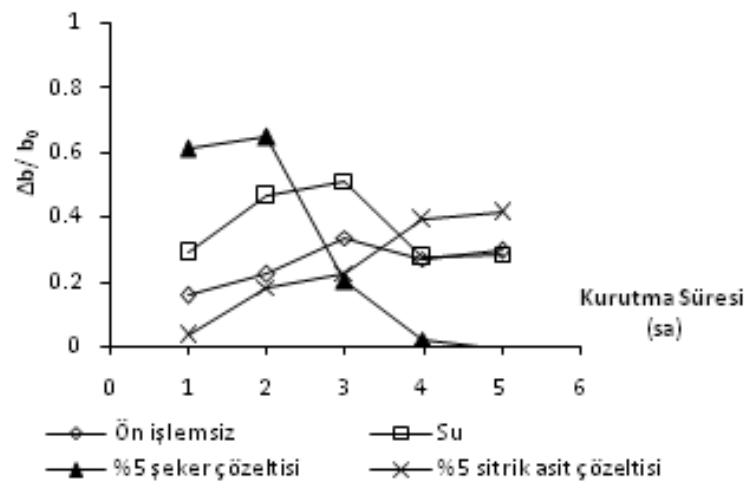

Şekil 5. Kurutma süresi boyunca $\Delta b / b_{o}$ değişimi 
Güneş enerjili kurutucuda kurutmada ön işlemin kurutma performansına olumlu etkisi olduğu görülmüştür. Sitrik asit çözeltisine daldırılmış muz halkalarının nem kaybı ve büzülme oranı diğer daldırma çözeltilerine göre daha fazla iken renk değişimi daha azdır.

Sitrik asit çözeltisine daldırılmış muz halkaları güneş altında, gölgede ve güneş enerjili kurutucuda kurutulmuş ve kurutma süresi boyunca nem kaybı değişimi şekil 6 de verilmiştir. Kurutma süresi boyunca muz halkalarının nem kaybı artmıştır. Nem kaybı en fazla güneş enerjili raflı kurutucuda olmuştur.

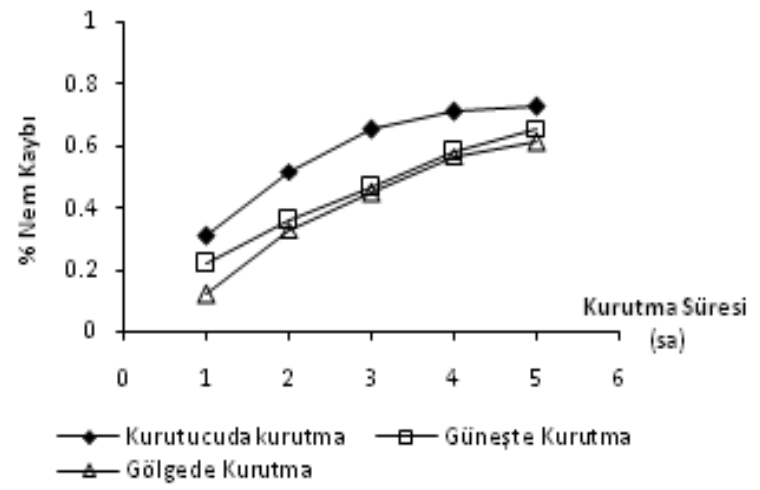

Şekil 6. \%5 sitrik asit çözeltisine daldırılmış muz halkalarının nem kaybı değişimi

Sitrik asit çözeltisine daldırılmış muz halkaları güneş altında, gölgede ve güneş enerjili kurutucuda kurutulma süresi boyunca büzülme oranındaki değişim şekil 7 de verilmiştir. Kurutma süresi boyunca muz halkalarının büzülme oranı en fazla güneş enerjili raflı kurutucuda en az gölgede kurutma da olmuştur.

Sitrik asit çözeltisine daldırılmış muz halkaları güneş altında, gölgede ve güneş enerjili kurutucuda kurutulması boyunca büzülme oranındaki değişim Şekil 8 de verilmiştir. Kurutma süresi boyunca muz halkalarının $\Delta b / b_{0}$ oranı artmıştır. Kurutma sıcaklığı arttıkça ürün rengi olumsuz etkilenmektedir. Daha düşük sıcaklıkta yapılan gölgede kurutmada sarı renk değişimi daha az olmuştur. En fazla b parametresinde değişim yüksek sıcaklıktan dolayı güneş enerjili rafıı kurutucuda olmuştur.

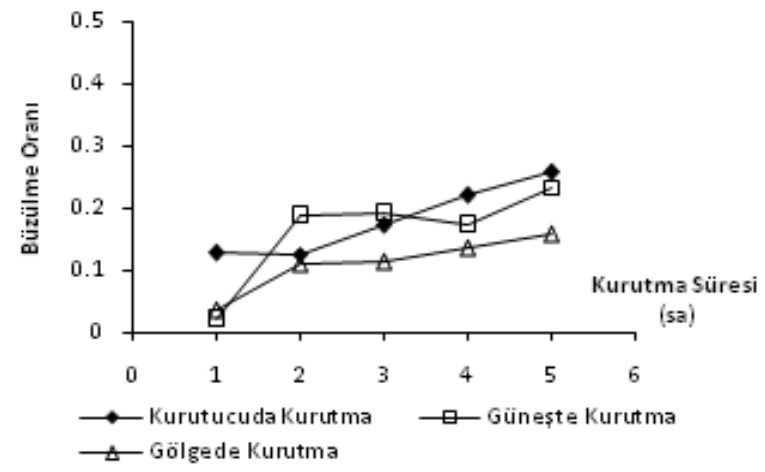

Şekil 7. \%5 sitrik asit çözeltisine daldırılmış muz halkalarının büzülme oranı değişimi

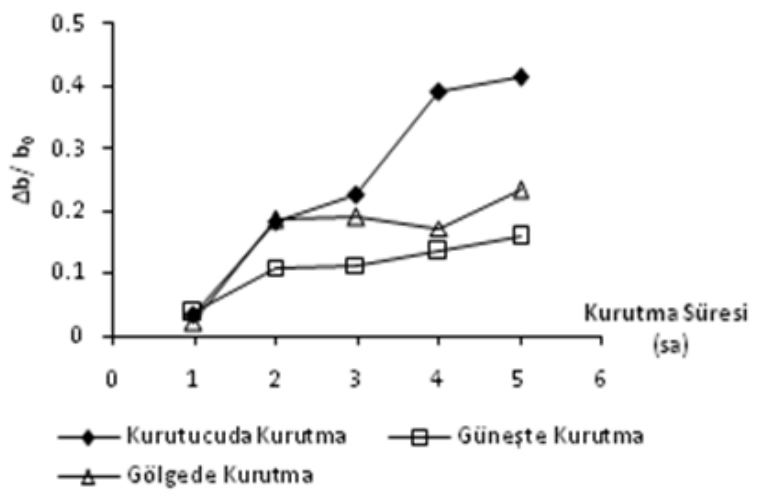

Şekil 8. \%5 sitrik asit çözeltisine daldırılmış muz halkalarının $\Delta \mathrm{b} / \mathrm{b}$ 。 değişimi

Ön işlemsiz ve ön işleme tabii tutulmuş muz halkalarının raflı güneş enerjili kurutucuda kurutulmasında ön işleminin kurutma performansını arttırdığı görülmüştür. Kurutma performans kriterlerinden en önemlisi olan nem kaybı tüm ön işlem görmüş muz halkalarının kurutulmasında ön işlemsiz kurutmaya göre daha fazla olmuştur. En fazla şeker çözeltisine batırılan muz halkalarında nem kaybı artışı belirlenmiştir. Nem kaybı fazla olmasına rağmen şekerli çözeltide bekletilen muz halkalarında büzülme diğerlerinkinden daha az olmuştur. Büzülme oranı ise en fazla sitrik asite daldırılan daldırılan muz halkalarında görülmüştür. Muz halkaları beyaz-sarı renklerinde olup, kesildikten sonra oksidasyon sebebiyle zamanla kararmaktadır. Ancak sitrik asit çözeltisine daldırılan muz halkalarında bu kararma önemli miktarda azalmıştır. Deneylerden elde edilen verilere göre raflı güneş enerjili kurutucuda kurutmadan önce muz halkalarının ön işlem ile kurutulmasının nem kaybı ve renk değişiminde olumlu etkileri olduğu görülmüştür.

\section{SONUÇ}

Kurutma tekniğinin geliştirilmesi üzerine yapılan bu çalışmada, kurutma işlemi öncesi uygulanan termal ön işlemin önemli etkileri olduğu ortaya çıkmıştır. Ön işlem uygulanmış tüm kurutma işlemlerinde nem kaybı ve büzülme oranı ön işlemsiz kurutma işlemlerine göre daha fazla olmuştur. En fazla nem kaybı ile beraber büzülme oranı \% 5 sitrik asit çözeltisine daldırılıp güneş enerjili kurutucuda kurutulan muz halkalarında meydana gelmiştir. Ön işlem uygulanmadan kurutulan muz halkalarının beş saatlik kurutma süresi sonunda nem kaybı \%55 iken sitrik asit çözeltisine daldırılmış örneklerin nem kaybı \%73 e yükselmiştir. Ön işlem uygulanmadan kurutulan muz halkalarının beş saatlik kurutma süresi sonunda büzülme oranı \%19 iken sitrik asit çözeltisine daldırılmış örneklerin nem kaybı \%26 a yükselmiştir. Bu sonuç, termal ön işlemin güneş enerjili kurutmada önemli olduğu göstermektedir. Ayrıca renk değişiminin daha az olduğu daldırma çözeltisi sitrik asit çözeltisi olduğu belirlenmiştir. Güneş enerjili kurutucuda kurutmanın güneş altında ve gölgede kurutmaya göre nem kaybı daha fazla olurken renk değişimi daha az olmuştur. Ticari değeri yüksek olan renk kalitesinin 
kurutulurken az etkilendiği yoğun kuru madde içeriğine ve uzun raf ömrüne sahip muz cipsi elde etmek için termal ön işlem ile güneş enerjili kurutma yönteminin birlikte kullanılabilir.

\section{KAYNAKLAR}

Abano EE, Sam-Amoah LK (2011) Effects of Different Pretreatments on Drying Characteristics of Banana Slices. ARPN Journal of Engineering and Applied Sciences 6(3): 121-129.

Aboud A, (2013) Drying Characteristic of Apple Slices Undertaken The Effect of Passive Shelf Solar Dryer and Open Sun Drying. Pakistan Journal of Nutrition, 12(3): 250-254.

Apaydın N (2007) Aydın Yöresinde İncir Kurutmada Kullanılacak Olan Doğal Akımlı Bir Güneş Enerjili Kurutucunun Modellenmesi. Yüksek Lisans Tezi, Adnan Menderes Üniversitesi, Aydın.

Akova SB, Güven Ş (2018) Mersin Meyveciliğinde Muzun Yeri ve Önemi. Marmara Coğrafya, 37: 271-289.

Aktas M, Ceylan i, Dogan H (2006) Günes Enerjili Kurutma Fırınında Elma Kurutması. Politeknik Dergisi, 289-294

Askari GR, Emam-Djomeh Z, Mousavi SM (2008) Investigation of The Effects of Microwave Treatment on The Optical Properties of Apple Slices During Drying. Drying Technology 26: 1362-1368.

Buldum B (2008) Yenilenebilir Enerji Kaynaklarından Güneş Enerjisinden Temiz Enerji Elde Etme Uygulamaları ve İktisadi Faydaları. Mali Ufuklar, 76-81.

Çakır M (2015) Güneş Enerjisinden Yararlanarak Tarım Ürünlerinin Kurutulması. Gazi Mühendislik Bilimleri Dergisi, 1 (1): 41-55.

Darıcı S (2012) Kivi Meyvesinin Kurutulmasında Kurutma Havası Hızının Kurumaya Etkisinin Incelenmesi. Tesisat Mühendisliği Dergisi, 20(130): 51- 58.

Enerji İşleri Genel Müdürlüğü, Güneş enerjisi Potansiyel Atlası, ttps://gepa.enerji.gov.tr/MyCalculator/33.aspx (Erişim Tarihi: 01/03/2021)

Eren i (2004) Patateslerin Osmotik Dehidrasyonunun Response Surface Metodu Kullanılarak Optimizasyonu. Yüksek Lisans Tezi, Ege Üniversitesi, İzmir.

Ertekin C, Yaldız O (1998) Bazı Sebze Meyve Ve Baharatlı Bitkilerin Kurutulma Yöntemleri Ve Kullanılan Güneş Enerjili Kurutucular. Tarımsal Mekanizasyon 18. Ulusal Kongresi. Tekirdağ.

Erünal S (2010) Prunus Domestica Ozmotik Dehidrasyon Parametrelerinin Ve Kurumaya Etkisinin İncelenmesi. Yüksek Lisans Tezi. Afyon Kocatepe Üniversitesi. Afyon.

Fernandes FA, Rodrigues S, Gaspareto OC, Oliveira EL (2006) Optimization of Osmotic Dehydration of Bananas Followed by Air-Drying. Journal of Food Engineering 77(1): 188-193.

Gürel AE, Ceylan i, Aktaş M (2016) Meyve ve Sebzelerin Kurutma Parametrelerinin İncelenmesi. Gazi Üniversitesi Fen Bilimleri Dergisi Part:C, Tasarım Ve Teknoloji, 4(4): 267-273.
Jagannath A, Kumar M (2016) Monitoring Blanching Induced Debittering and Storage Losses of Naringin in Orange Subjected to Osmotic Dehydration. International Journal of Fruit Science 16(4): 1-13.

Lingayat A, Chandramohan VP, Raju VRK (2017) Design, Development and Performance of Indirect Type Solar Dryer for Banana Drying. Energy Procedia 109: 409 416.

Maskan M (2001) Kinetics of Colour Change of Kiwifruits During Hot Air and Microwave Drying. Journal of Food Engineering 48:169-175.

Nwakuba NR, Chukwuezie OC, Asonye GU, Asoegwu SN (2018) Energy Analysis and Optimization of Thin Layer Drying Conditions of Okra. Arid Zone Journal of Engineering. Technology and Environment 14: 135154.

Nowakunda K, Andrés A, Fito P (2004) Osmotic Dehydration of Banana Slices As A Pretreatment for Drying Processes. In The International Drying Symposium, 14: 2077-2083.

Pandya R, Yadav KC (2014) Study on Effect of Pretreatments and Microwave Drying on Banana Chips. IOSR Journal of Agriculture and Veterinary Science IOSR-JAVS, 7(7): 04-10.

Silva Júnior AF, Silva WP, Farias AJE, Aires KLCF, Castro DS (2017). Osmotic Dehydration Kinetics of Banana Slices Considering Variable Diffusivities and Shrinkage. International Journal of Food Properties, 20(6): 13131325.

Subaşı OS, Seçer A, Yaşar B, Emeksiz F, Uysal O (2016) Production Cost and Profitability of Banana in Turkey. Mediterranean Agricultural Sciences, 292: 73-78.

Sunitha VB, Krishnaveni R, Lavanya A, Vyshnavi T (2017) Study on Effect of Quality of Green Banana Flour Using Different Drying Techniques. The Pharma Innovation Journal 6(10): 01-07.

Taiwo KA, Adeyemi O (2009) Influence of Blanching on The Drying and Rehydration of Banana Slice. African Journal of Food Science 3(10): 307-315.

Talla A, Puiggali JR, Jomaa W, Jannot Y (2004) Shrinkage and Density Evolution Duringdrying of Tropical Fruits: Application to Banana. Journal of Food Engineering 64: 103-109.

Yıldız AK, Polatcı H, Ucun H (2015) Farklı Kurutma Şartlarında Muz Meyvesinin Kurutulması ve Kurutma Kinetiğin Yapay Sinir Ağları İle Modellenmesi. Tarım Makineleri Bilim Dergisi, 11(2): 173-178.

Yıldız Z, Gökayaz L (2018) Çok Raflı Günes Enerjili Kurutucuda Elma Kurutulması. 3rd International Mediterranean Science and Engineering Congress, Adana.

Yokuş B (2014) Farklı Ön İşlemlerin ve Uygulanan Farklı Kurutma Yöntemlerinin Elmada Toplam Fenol Miktarı ve Antioksidan Aktivite Üzerine Etkileri. Yüksek Lisans Tezi, Bilecik Şeyh Edebali Üniversitesi, Bilecik. 